\title{
Study on Using Experiential Teaching Mode in the University Civil Engineering Safety Course
}

\author{
Tang Jingjing ${ }^{a}$, Zou Yuming ${ }^{b}$ \\ School of Civil Engineering, Huazhong University of Science \& Technology, Wuhan Hubei, China \\ atjj97@126.com, bou_yuming924@yahoo.com
}

Keywords: Civil engineering; Safety education; Engineering safety courses; Experiential teaching;
Didactic teaching

Abstract. In order to adapt to the construction industry's trend of development and meet the demand for interdisciplinary talents who are familiar with production and safety, it is very necessary for civil engineering universities to offer courses about safety. Based on the current situation of civil engineering safety courses and safety education in university, this study analyzed the limitations that traditional didactic teaching method has, and then revealed that reform and innovation must be enforced towards engineering safety education. Combined with teaching practice in Huazhong University of Science and Technology excellent course, Project Safety and Disaster Prevention \& Reduction, this study investigated positive impacts and implementation if the experiential teaching is introduced into the civil engineering safety courses in university.

\section{Introduction}

Second to coal mining industry, construction industry is one of the largest high-risk industry, in which accidents take place frequently. According to the Bulletin of Housing Municipal Engineering Production Safety Accidents, although the number of accidents and deaths during the housing municipal engineering process has a trend to decrease in the last decade [Fig.1], the absolute amount still tends to be high. Especially in the recent two years, some rebound phenomena happen: the number of people who died by accident in 2013 is $39.7 \%$ higher than 2012. It is obvious that the situation about safety production in construction engineering is still very serious.

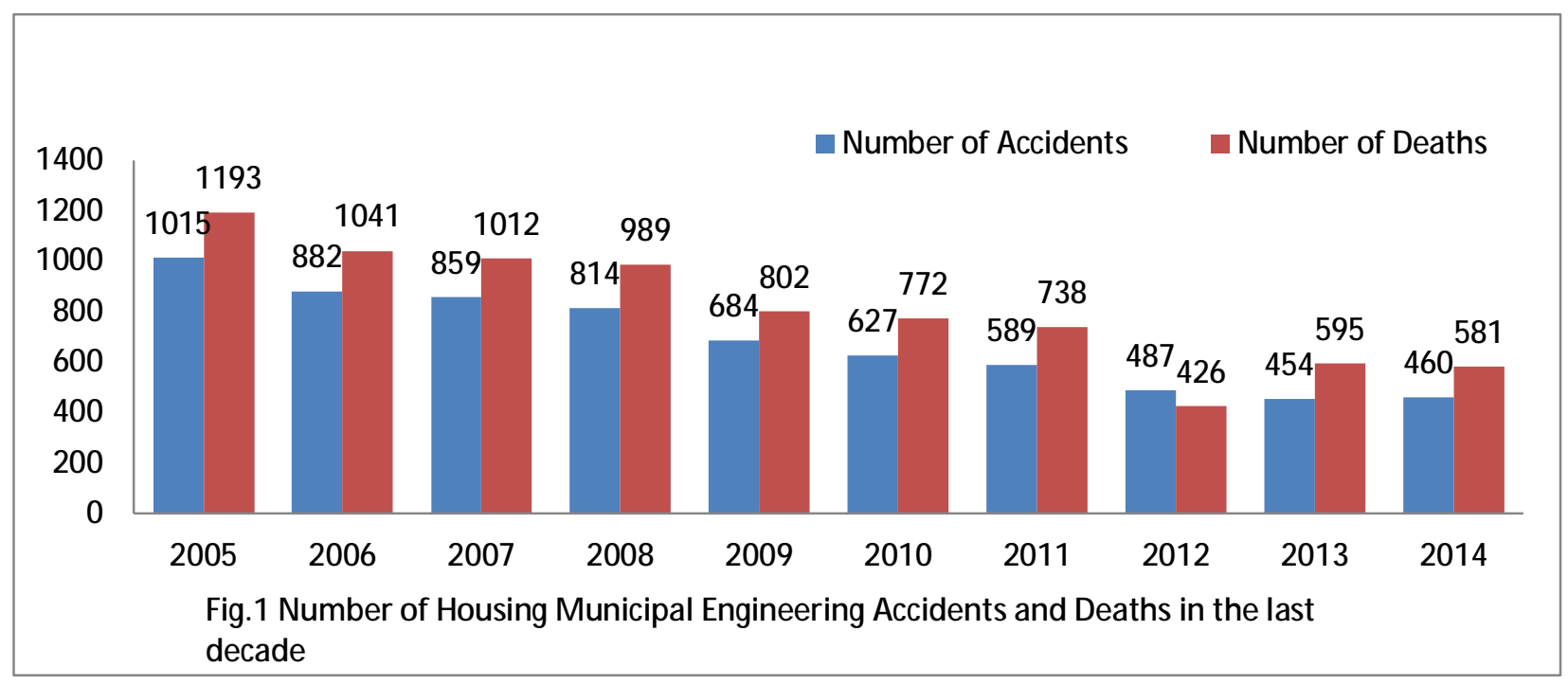

One of the underlying cause of engineering safety accidents is people's unsafe behavior, which means managing staff's and operating staff's behavior violate the safety production objective regulations. In the process of construction, professional managers' and senior technicians' behavior can be of vital importance for safety production, while their behavior relates closely to their higher engineering education [1]. University should take engineering safety as one of the main courses for Engineering Majors. Student can form complete knowledge system of engineering safety gradually by 
learning the knowledge related to engineering safety, such as basic theories, professional skills, specialized tools, moral principles[2]. In this way, university can cultivate interdisciplinary talents who are familiar with professional knowledge of engineering and safety production management.

\section{Present Situation and Limitations of Traditional Civil Engineering Safety Course Didactic Teaching}

Take Construction Management as an example, 16 universities out of 37 "985-project" universities set undergraduate program of Construction Management. Among these universities, 4 universities offer engineering safety courses: required course Safety and Health in Construction and elective course Analysis of Constructional Structure Accident and Reinforcement in Tsinghua University, two elective courses including Construction Disaster Prevention \& Reduction and Analysis and Treatment of Construction Accident in Zhejiang University, required course Project Safety and Disaster Prevention \& Reduction in Huazhong University of Science and Technology(HUST), and required course Introduction to Disaster Prevention \& Reduction in Central South University.

HUST has been offering Project Safety and Disaster Prevention \& Reduction since 2004, which is in the charge of Department of Construction Management in the School of Civil Engineering and Mechanics. Being a main platform course for 9 undergraduate majors including Civil Engineering, Construction Engineering, Architecture, Environmental Engineering from School of Civil Engineering and Mechanics, School of Architecture and Urban Planning, and School of Environmental Science and Engineering, this course has been developed as an excellent course and excellent video course in HUST.

Survey showed that traditional theoretical teaching, also called didactic teaching, is widely adopted in universities' Civil Engineering classroom. This teaching mode's main deficiencies and limitations is pointed out below:

1. Most of the teaching contents are theoretical knowledge. However, practice is of great importance for engineering students at school. Contrary to other subject, the primary task of engineering safety production safety education is to help students to establish the concept that safety is first. Besides, today's university students have a common feature of a strong self-learning ability but are also prone to be weary of learning. Course setting related closely to actual engineering situation is in demand, in order to arousing students' enthusiasm for learning.

2. Teacher is the dispenser of theoretical knowledge while students are the recipient of passive study. In this mode of didactic teaching, a teacher's job is to compile textbook, improve courseware and evaluate how well students master the knowledge he have taught. Students are supposed to take notes, recite notes, take exam in the designated contents about their notes. What the university concerns is an integral curriculum system rather than the teaching mode and its teaching effectiveness.

3. Traditional evaluation stresses more on theory than practice. Currently, every civil engineering safety course in university conducts the traditional evaluation form, of which usual performance takes $20 \% \sim 30 \%$ and paper based exam takes $70 \% \sim 80 \%$. The contents in paper based exam merely reflect students' degree of mastering the theoretic knowledge.

\section{Positive Impacts of Introducing Experiential Teaching into Civil Engineering Safety Education}

The comparison between traditional didactic teaching mode and experiential teaching mode can be seen in table 1. Apparently, experiential teaching mode emphasizes on the interaction between knowledge and learners, paying more attention to students' participation. Experiential teaching mode aims to inspire students and foster their creative thinking and practical ability. It respects individual differences and don't demand for same recognition. 
Table 1 Comparison Between Traditional Didactic Teaching Mode and Experiential Teaching Mode

\begin{tabular}{|l|l|}
\hline \multicolumn{1}{|c|}{ Experiential Teaching Mode } & \multicolumn{1}{c|}{ Didactic Teaching Mode } \\
\hline student-centered and guided by teacher & teacher-centered \\
\hline $\begin{array}{l}\text { emphasizes on acquiring knowledge } \\
\text { actively by experiencing it }\end{array}$ & $\begin{array}{l}\text { emphasizes on the passive one-way } \\
\text { transmission of knowledge }\end{array}$ \\
\hline $\begin{array}{l}\text { concentrates on learners' understanding } \\
\text { and realization }\end{array}$ & concentrates on teaching and memorizing \\
\hline emphasizes on "Knowing the knowledge" & emphasizes on "learning the knowledge" \\
\hline personalized learning & standard learning \\
\hline combines theory and practice & theoretical \\
\hline
\end{tabular}

Concluded from Table 1, devising practical and novel education situation is encouraged by experiential teaching mode. In this situation, student can experience different construction engineering safety production. Autonomic engineering safety awareness can be set up through student's reflection and discussion. Compared to traditional didactic teaching mode, experiential teaching mode pay more attention on every student's own inner education. Introducing it to the university's Civil Engineering safety classroom have some positive meanings.

1. Experiential teaching mode suits current developing trend and the demand of university student's physical and mental development. Differ from traditional teaching mode, experiential teaching mode has 4 character: participation, diversity, entertaining, and understanding. It do not only meet the demand of practical civil engineering safety course in university, but also motivate students to learn with enthusiasm, giving rise to a better teaching result.

2. Experiential teaching mode build upon learner's personal experience, which is benefit for student to absorb the knowledge they have learned. Psychological research observed that the proportion of information human can remember by seeing and hearing are $10 \%$ and $20 \%$ respectively while information can be remembered by personal experience reaches to $80 \%$. Obviously, in didactic teaching mode, no matter how many words teacher has said, the result is much less effective than experiential teaching mode in which students can experience what they learned by personal practice.

3. Experiential teaching mode can enhance teacher-student interaction and improve academic communication. Due to the rapid development of information technology, student can acquire knowledge through many sources while teacher is not a monopolist of knowledge anymore. Experiential teaching mode can help realize both teacher's and student's goal of studying together and making a progress together. Even flipped classroom is able to be achieved in the future. In this way, teaching benefits teachers as well as students.

\section{Implementation of Experiential Teaching in Civil Engineering Safety Education}

Fostering engineering students' engineering practical ability, engineering design ability and engineering innovation ability is the goal of engineering educational reform, aiming to let education return back to engineering practice. It is difficult to change the traditional teaching mode used by current civil engineering safety classroom which is textbook-centered, teacher-centered, classroom-centered. Teacher should devise their teaching approach more elaborately. Subsequently, based on Project Safety and Disaster Prevention \& Reduction course teaching and civil engineering Civil Engineering and Management Social Practice education, several experiential teaching approaches for safety production course will be introduced:

Engineering Safety Case Based Experiential Teaching. Case based experiential teaching takes some significant engineering safety accidents as the main line. Teaching goals can be achieved by student's experiential learning. First, teacher introduces the engineering project's background and 
general situation of the safety accident. Then, teacher guides students to analyze the cause, responsibility, corrective action and so on. Finally, summary is supposed to be made with the combination of expert opinion in the Accident Investigation Report. In case based experiential teaching, civil engineering safety management and professional knowledge of engineering are integrated with the analysis of a specific construction case. It helps to enliven classroom atmosphere and improve student's self-consciousness of learning. The interaction between teacher and students is promoted.

Illegal Operation Simulation Based Experiential Teaching. Simulation based experiential teaching follows the theory of reflection. Vivid and specific teaching situation along with role playing can be used, which can arouse student's learning enthusiasm. Through comprehensive understanding and practical applying of safety knowledge, student can develop their knowledge, quality and ability together. Initially, teacher designs one safety production accidental situation, and then choses a student or students group to play the simulation roles. In the scene simulation, student can experience potential danger and possible serious consequence caused by illegal operation and command.

Construction Safety Skills Practical Training Based Experiential teaching. Only through on-site construction practice can student truly grasp the keynotes of related safety production skills and the importance of necessary construction regulations. Besides lecturing with the help of any sorts of safety knowledge audio-visual materials, teacher is supposed to demonstrate personally. Multi-experience teaching activities should be devised for students, such as the way to wear a helmet, technical points to build scaffold, regulations to remove formwork. Students are asked to observe teacher's demonstration. After grasping the key steps and operations, students can practice on their own. Student can improve the operative ability and master the skills.

Experiential Safety Education Training Device for Self-research and Development. Holding the belief that student is not only the recipient but also a designer of experiential safety production education, teachers in Civil Engineering Institute for Security Study, School of Civil Engineering and Mechanics, HUST, guided civil engineering master students develop an intelligent experiential safety education training device about high falling, which has declared the national patent for invention. In the process of the development, students applied the knowledge of construction structure design, and they also participate actively in the design of experiential safety production education mode.

Extension from Experiential Teaching Mode to Extracurricular Activities and Competitions. Experiential safety production teaching can be implemented by several means, including open class, college student extracurricular innovation training program, extracurricular professional competition and so on. Students can improve their research ability, writing ability and competition consciousness. Moreover, outstanding students can earn bonus points for postgraduate recommendation. These activities are popular among students. For example, some students accomplished an animation presentation about the types and causes of tower crane accidents, based on their literature review and social investigation towards real accident cases. And they won an award in National Construction Management Innovation Competition organized by Tsinghua University.

\section{Conclusions}

Olin College of Engineering in America promotes project-based experiential learning mode vigorously, reconstruct curriculum system and training process, featuring interdisciplinary and design-oriented. Especially in nowadays, this education reform receives the whole American even the whole world's attention as a model [4]. Experiential safety production teaching mode is the product of time progress, the certain development of modern construction safety training system. This teaching mode combines theoretical teaching and practical experience, letting knowledge and experience take interaction with each other, also strengthening learner awareness about the importance of safety production remarkably. In current China's higher education reform, using modern teaching means (computer, network technology, multimedia, etc.) and various teaching modes (case teaching, practice teaching, interactive teaching, inquiry teaching, etc.) can improve teaching quality and teaching level significantly. On the one hand, the successful implementation of these teaching modes provides university civil engineering 
safety course with good reference about experiential teaching. On the other hand, it build a solid foundation for experiential teaching to be introduced into university's civil engineering safety course.

\section{Corresponding Author}

\section{Zhao Tingsheng}

School of Civil Engineering, Huazhong University of Science \& Technology, Wuhan Hubei, China tszhao@mail.hust.edu.cn

\section{Subject Source}

Teaching Research Subject in Hubei Province, Cultivation Mode Research of Safety Science

Knowledge and Innovation Ability towards Civil Engineering Outstanding Talents

\section{References}

[1] Zhao. W, Liao. W, Dai. N, in: Engineering Safety and Training of Its Professionals (In Chinese), volume 16 of China Safety Science Journal (2006), p.71-75

[2] Wang. Y, in: Innovation Research of Construction Safety Management Talents Cultivating Mode (In Chinese), unpublished master dissertation, Capital University of Economics and Business (2013)

[3] Shi. Y, in: Research on the Effect of Applying Experiential Teaching Mode to "Civil Engineering Construction and Management" Course (In Chinese), issue 19 of The Science Education Article Cultures (2014), p.67-68

[4] Wu. J, Zou. X, in: Return to Engineering Practice (In Chinese), issue 1 of Research in Higher Education of Engineering (2013), p.40-45 T 